\title{
Karl Ewald Konstantin Hering (1834-1918), Heinrich Ewald Hering (1866-1948), and the namesake for the Hering-Breuer reflex
}

\author{
Anand N. Bosmia ${ }^{1} \cdot$ Emanuela Binello $^{2}$ - Christopher J. Griessenauer ${ }^{1}$. \\ R. Shane Tubbs ${ }^{1} \cdot$ Mohammadali M. Shoja ${ }^{1,3}$
}

Received: 18 July 2015 / Accepted: 20 July 2015 / Published online: 5 August 2015

(C) Springer-Verlag Berlin Heidelberg 2015

\section{Introduction}

Medical eponyms are a component of the jargon employed by clinicians and scientists, and exploring the history behind such terms is an undertaking enjoyed by enthusiasts for the study of medical history. The Hering-Breuer reflex is mediated by the afferent fibers of the vagus nerve and consists of the inhibition of inspiration by inflation of the lungs and the inhibition of expiration by deflation of the lungs [18], which thereby limits respiratory excursions [9]. Multiple references incorrectly identify Heinrich Ewald Hering (1866-1948) as the man for whom the Hering-Breuer reflex is named, but this medical eponym actually refers to Heinrich Ewald Hering's father, the physiologist Karl Ewald Konstantin Hering (18341918). For the purpose of clarity, the authors refer to Karl Ewald Konstantin Hering as "Hering Senior" and Heinrich Ewald Hering as "Hering Junior" in this manuscript.

\section{Karl Ewald Konstantin Hering (1834-1918) and Josef Breuer (1842-1925)}

Karl Ewald Konstantin Hering, or Ewald Hering (Fig. 1, cover picture), was born in Altgersdorf in southern Prussia and

Mohammadali M. Shoja

shoja.m@gmail.com

1 Pediatric Neurosurgery, Children's Hospital, 1600 7th Avenue South ACC 400, Birmingham, AL 35233, USA

2 Department of Neurosurgery, Boston University School of Medicine, Boston, MA, USA

3 Medical Philosophy and History Research Center, Tabriz University of Medical Sciences, Tabriz, Iran studied medicine in Leipzig from 1853 to 1858 [5]. He maintained an interest in the physiology of vision throughout his life and published research on visual space perception while practicing medicine [17]. In 1865, Hering Senior succeeded Carl Ludwig as professor of physiology at the Josephinum, a military medical school in Vienna that was separate from the university, and in 1869 succeeded Jan Purkinje as professor of physiology in Prague [17]. Koller's paper Vorlaufige Mittheilung über locale Anasthesirung am Auge, which was published in volume 22 of Klinische Monatsblätter für Augenheilkunde in 1884, notes that Hering Senior was appointed a university lecturer in Vienna in 1868, and Theodore Billroth's “Open Letter to Dr. Wittelshofer”, which was published in volume 31 of Wiener medizinische Wochenschrift in 1881, notes that 3 years following this appointment, Hering the Father withdrew to begin private practice and refused a professorial title to which he had been recommended by Theodore Billroth (1829-1894) [18]. Hering Senior worked in Prague on the theory of vision and perception of colors, and his results were published in a series of contributions titled Zur Lehre vom Lichtsinne from 1872 to 1874 [16].

Josef Breuer (1842-1925), the other individual for whom the Hering-Breuer reflex is named, was born in Vienna and studied medicine at the University of Vienna [12]. Breuer was an associate and colleague of Sigmund Freud (1856-1939) and published with Freud the book Studien uber Hysterie in 1895 (Fig. 2), which was very influential in the development of psychoanalysis and depth psychology; Freud dedicated his first book, Aphasia, to Breuer in 1891 [18]. Hering Senior collaborated with Breuer, at the time a young student, in work on the physiology of respiration, an endeavor that lead to the discovery of the Hering-Breuer reflex [5, 17] and produced two papers that appeared in 1868, each of which are titled Die Selbststeuerung der Atmung durch den Nervus vagus ("The 

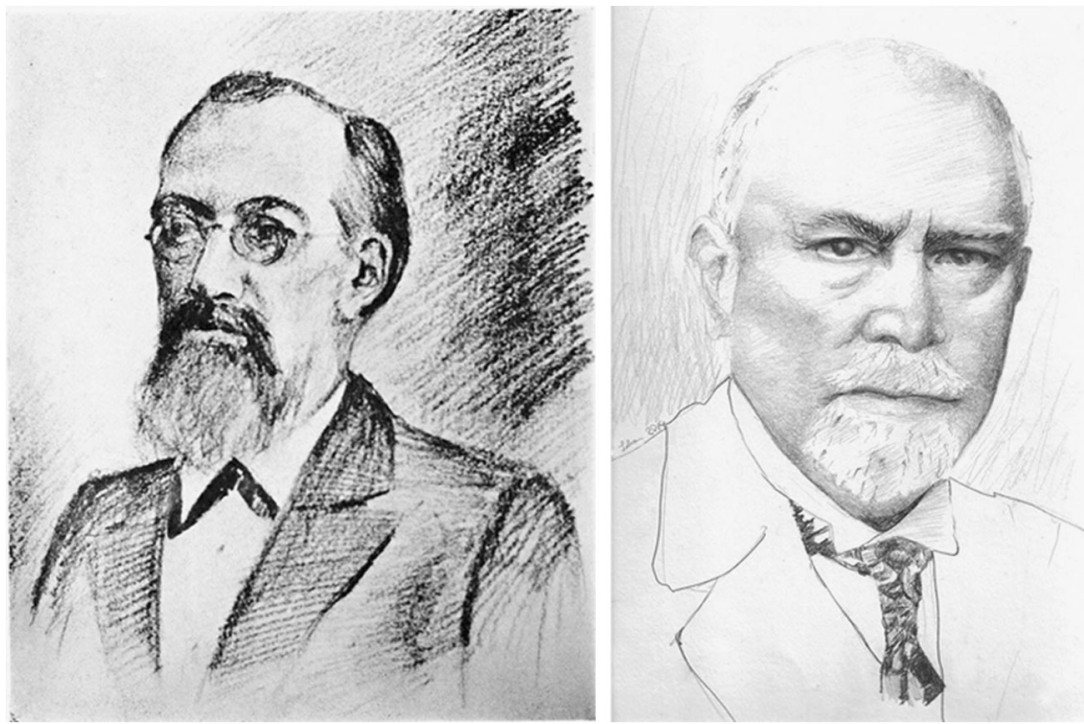

Fig. 1 and cover figure Left: Pencil portrait of Karl Ewald Konstantin Hering (1834-1918) from the Reynolds-Finley Historical Library's copy of Spatial Sense and Movement of the Eye, by Ewald Hering (Baltimore: The American Academy of Optometry, 1942). Unknown artist, sketched from photograph by George Beattie, Jr. Image courtesy of

self-control of the respiration through the vagus nerve") $[4$, $15]$.

\section{Henry Head (1861-1940) and Karl Ewald Konstantin Hering (1834-1918)}

The English neurologist Henry Head (1861-1940; Fig. 3) worked in Hering Senior's laboratory at the physiology department of the German University in Prague from 1884 to 1886 [3]. Head was a 23-year-old medical student at Cambridge when he interrupted his studies to do research with Hering Senior, and Head acknowledge the influence of Hering Senior in the preface to his book Aphasia and Kindred Disorders [24]. Head's research with Hering Senior concerned the self-regulation of breathing and resulted in the publication of two papers in 1889 in the Journal of Physiology: "On the Regulation of Respiration. Part 1. Experimental" and "On the Regulation of Respiration. Part 2. Theoretical" [17]. At the time of Head's research experience, Hering Junior was 18 years old (and therefore likely not the mentor to the 23year-old Head).

However, the confusion regarding the respective careers of Hering Senior and Hering Junior also extends even to this collaboration. Gardner-Thorpe [11] notes the collaboration of Henry Head and Josef Breuer with "Hering" but writes that Head and Breuer worked with Heinrich Ewald Hering and subsequently credits Hering Junior with research in color vision actually done by Hering Senior: "In September 1884 he [Head] went to Cologne to visit the Austrian physiologist, Heinrich Ewald Hering (1866-1948) who, in 1868, with
Reynolds-Finley Historical Library, the University of Alabama at Birmingham. Right: Pencil portrait of Heinrich Ewald Hering (i.e., Hering Junior) by an artist, Salva M. Shoja (2015), sketched from a photograph (\#179698) on the US National Library of Medicine, the History of Medicine Images Collection

Breuer had described the reflex later named the HeringBreuer reflex...[Head] studied the physiology of respiration, carried out experiments with the vagus, learned histology, and listened to Hering's account of research into color vision."

\section{Heinrich Ewald Hering (1866-1948)}

Hering Junior (Fig. 1) was born in Vienna, while his father was Rector of the German University in Prague [6, 21]. In 1905, Hering Junior became interested in Czermark's observation of cardiac slowing attributed to mechanical pressure on the vagus nerve in the neck. Johann Nepomuk Czermak (1828-1873) had noted in a paper published in 1866 titled Über mechanische Vagus Reizung beim Menschen ("On the Mechanical Irritation of Vagus in Humans") [8], that he had been able to elicit a negative chronotropic effect on the heart rate by applying pressure on his right vagus nerve [17, 25]. Czermak's self-experiment inspired Hering Junior to do research in the field of cardiovascular physiology; however, he did not have time to pursue the matter until after becoming Professor of Normal and Pathological Physiology at the University of Cologne in 1914.

Rihl's paper "Hering on his 70th Birthday", which was published in volume 15 of Klinische Wochenschrift in 1936, notes that he "enriched our understanding of cardiovascular function with the interpretation of the carotid sinus reflex, experimental studies on the independent action of auricles and ventricles, and the analysis of pulsus irregularis perpetuus." Hering Junior matriculated at the University of Prague, where he was appointed professor of general and 
Fig. 2 Title page of Studien uber Hysterie (Studies on Hysteria) written by Josef Breuer and Sigmund Freud, F. Deuticke, Leipzig and Vienna, 1895. Image courtesy of Wellcome Library, London

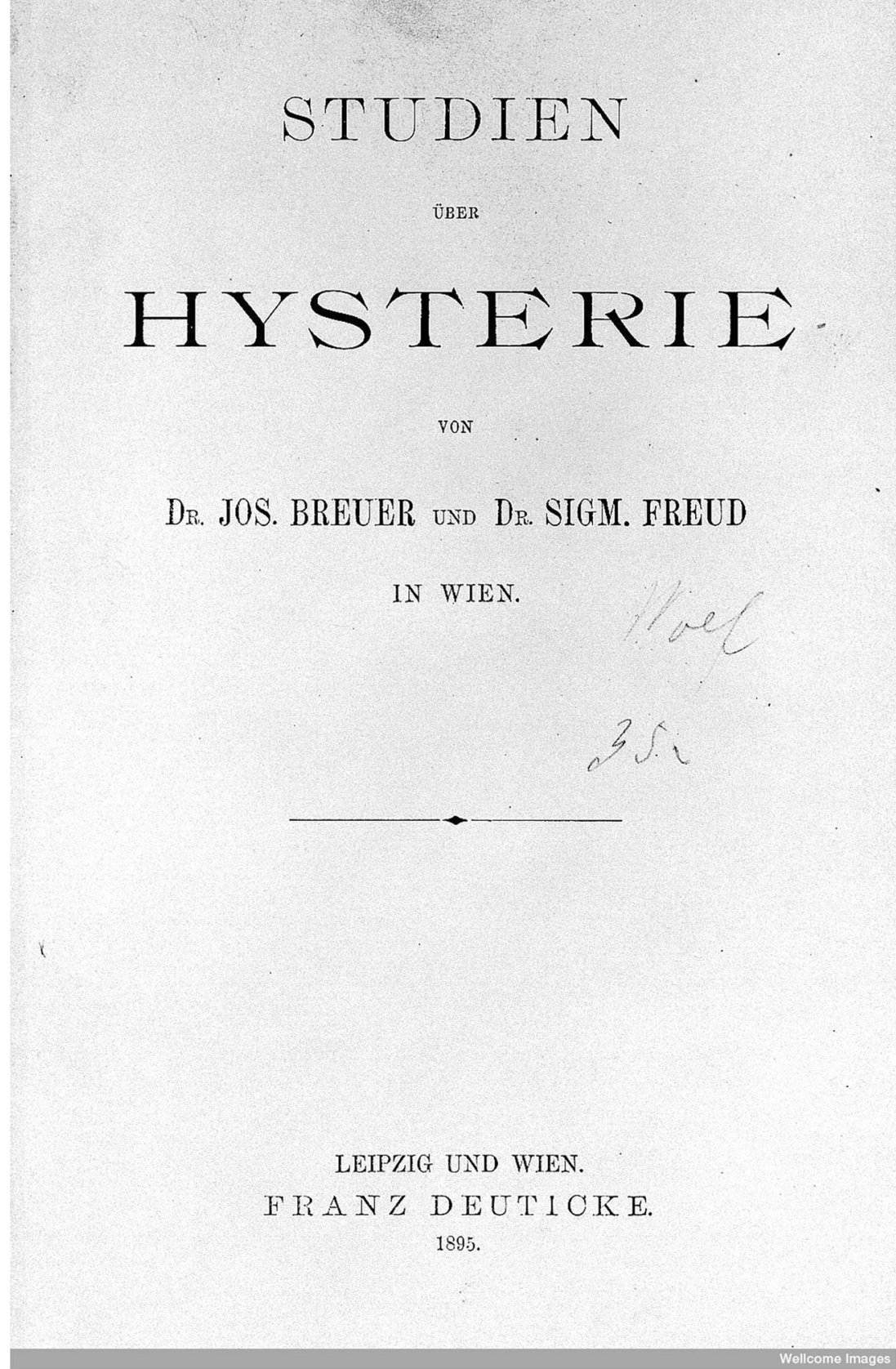

experimental pathology, and accepted an invitation to become Director of the Institute of Pathologic Physiology at the University of Cologne just before World War I [1]. Per Rothschuh in Geschichte der Physiologie published in 1953, he was appointed to this position in 1913 [25].

Hering Junior initially studied the innervation of skeletal muscle, and this research interest led him to study the physiology and pathology of the heart and great vessels and their correlation with clinical findings regarding the pulse rate and activity of the chambers of the heart [1]. In 1895, he reported that an almost instantaneous acceleration of the heart rate at the start of exercise is initiated by reduction of vagal tone [22]. At the German University in Prague, Hering Junior studied arrhythmias using the polygraph and described in 1903 the "pulses irregularis perpetuus" [1, 6, 13], which became known as auricular fibrillation and subsequently atrial fibrillation [10]. The Edelmann electrocardiograph became available in 1907, following which Hering and others on the European continent develop a great interest in clinical electrocardiography [6]. Hering Junior conducted studies on atrial fibrillation and other arrhythmias with the electrocardiogram between 1908 and 1913, and the significance of his studies is reflected in the fact that his work is referenced 51 times in Lewis' book The Mechanism and Graphic Registration of the Heart Beat (1920) [6]. In 1908, Hering Junior was probably the first to publish an electrocardiogram showing "no sign of action of 


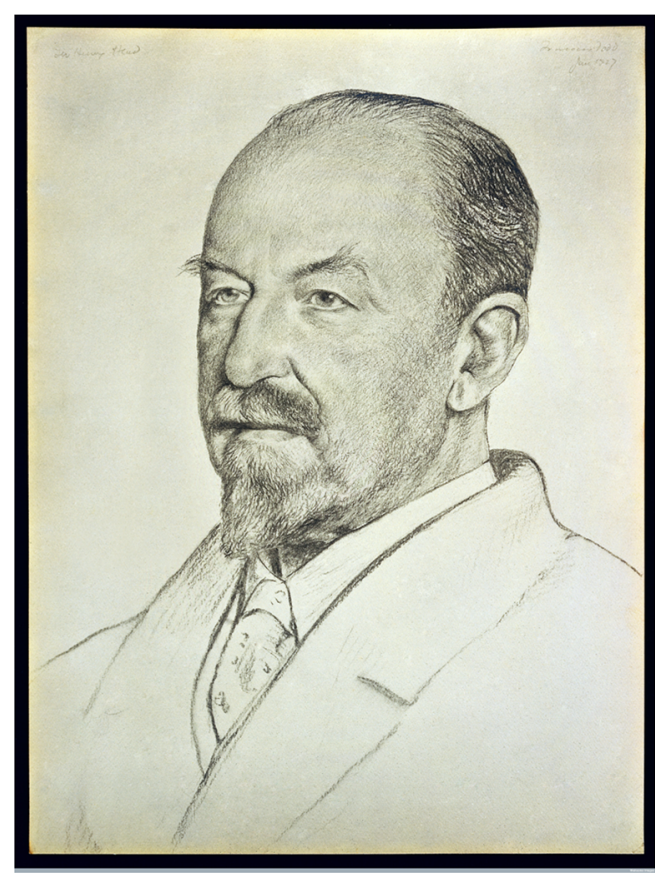

Fig. 3 Pencil portrait of Sir Henry Head by Marcus Dodd, 1927. Image courtesy of Wellcome Library, London

the supraventricular division of the heart [atrial fibrillation]" [6].

A notable medical eponym named after Hering Junior is Hering's nerve or sinus nerve of Hering, which refers to the carotid sinus nerve, a branch of the ninth cranial nerve, or glossopharyngeal nerve, that innervates the baroreceptors in the carotid sinus and the chemoreceptors in the carotid body $[2,9]$. Hering Junior described this nerve in 1923 [11] and reported his classic observations of the carotid sinus reflex in 1923 [20]. He observed in his 1923 publication Der Karotisdruckversuch ("The carotid pressure test") that pressure applied to the carotid sinus also elicits a negative chronotropic effect and thereby concluded that Czermak had not directly stimulated the efferent nerve but instead had stimulated the afferent sinus nerve and thereby elicited the carotid sinus reflex [25]. In 1924, Hering Junior noted,

"Using the so-called Czermak's vagal pressure test I found that its effects are not the result of pressure on the vagal nerve and the mechanical irritation of its heart inhibitory fibers, but due to a reflex from the carotid sinus, which is located at the origin of the internal carotid artery. I also found a second reflex emanating from the carotid sinus, which has a quite vigorous effect on reducing the blood pressure. Both reflexes, the heartinhibitory and vasodilatory, disappeared after denervation of the carotid sinus."

His experiments concluded, "The sinus reflexes originating from the carotid sinus are mediated by a branch of the glossopharyngeal nerve [14]," which he suggested to be referred to as the "sinus nerve." In 1927, he observed arterial hypertension when both carotid sinus nerves were cut and thereafter called these nerves blutdruckzügler and published these results in Karotissinusreflexe auf Herz und Gefässe, vom normalphysiologischen, pathologische-physiologischen und klinischen Standpunkt [20].

\section{The namesake for the "Hering-Breuer reflex"}

The seminal paper on the Hering-Breuer reflex, Die Selbststeuerung der Athmung durch den Nervus vagus ("The self-control of the respiration through the vagus nerve") was published in 1868, and this fact alone demonstrates that Hering Junior is not the namesake for the Hering-Breuer reflex. Hering Junior was born in 1866 and thus was aged 2 years at the time of the paper's publication. Multiple factors likely contributed to the confusion regarding this medical eponym's

Table 1 Resources erroneously attributing the Hering-Breuer reflex to Hering Junior

\begin{tabular}{|c|c|}
\hline References & Citation \\
\hline Corsini (2001) [7] & $\begin{array}{l}\text { "Hering-Breuer reflex: an automatic mechanism involved in normal breathing, with stimuli from sensory endings in lung } \\
\text { tissue limiting inspiration and expiration. Named after German physiologist Heinrich Ewald Hering (1866-1948)." }\end{array}$ \\
\hline Dorland (2011) [9] & "Hering-Breuer reflex (H.E. Hering; Josef Robert Breuer, Austrian physician, 1842-1925)." \\
\hline Glickstein (2014) [12] & $\begin{array}{l}\text { "As a young physician he [Josef Breuer] collaborated with Heinrich Ewald Hering, studying the reflex control of the vagus } \\
\text { nerve in respiration." }\end{array}$ \\
\hline Navarra (2003) [19] & $\begin{array}{l}\text { "Hering-Breuer reflex: named for German physiologist Heinrich Ewald Hering (1866-1948) and Austrian physician Josef } \\
\text { Breuer (1842-1925), the reflex inhibition of breathing in as a result of pressoreceptor-nerve stimulation when the lungs } \\
\text { are inflated." }\end{array}$ \\
\hline $\begin{array}{l}\text { Bartolucci and } \\
\quad \text { Forbis (2005) [2] }\end{array}$ & $\begin{array}{l}\text { "Hering, Heinrich Ewald, German physiologist, 1866-1948. Hering-Breuer reflex: inflation of the lungs arrests inspiration } \\
\text { with expiration then ensuing; deflation of the lungs brings on inspiration." }\end{array}$ \\
\hline White (2009) [23] & $\begin{array}{l}\text { "Hering-Breuer sign, [Heinrich Ewald Hering, Austrian physician, 1866-1948] the nervous mechanism which tends to limit } \\
\text { the respiratory excursions. Stimuli from the sensory endings in the lungs and perhaps in other parts passing up the vagi } \\
\text { tend to limit both inspiration and expiration in ordinary breathing." }\end{array}$ \\
\hline
\end{tabular}


namesake. For example, Hering Senior was sometimes referred to as "Ewald Hering", and this truncated version of his name may have been equated with the name "Heinrich Ewald Hering", thereby causing scholars to attribute the discovery of the Hering-Breuer reflex to Hering Junior instead of Hering Senior.

In addition, both Hering Senior and Hering Junior conducted studies involving the vagus nerves. Hering Senior studied the vagus nerve and its involvement in the regulation of breathing, and Hering Junior studied the effects of vagal tone on the pulse rate. Hering Senior's interest in the physiology of respiration led him to study its effects on the cardiovascular system, as evidenced by the publication of the article Über den Einfluss der Athmung auf den Kreislauf. 1. Über Athembewegungen des Gefässsystems ("On the influence of respiration on the circulation. 1. About respiratory movements of the vascular system") in 1869 [17, 22]. Thus, both Hering Senior and Hering Junior addressed the effects of the vagus nerve on cardiopulmonary physiology in their work, and this overlap may have contributed to the confusion regarding their respective careers. Tipton [22] mistakenly credits Hering Junior with publishing the aforementioned article; Hering Senior would have been 2 years old at the time of its publication. Unfortunately, the error of attributing the Hering-Breuer reflex to Hering Junior rather than Hering Senior has been propagated in the literature as shown in the references mentioned in Table 1.

\section{Conclusion}

Careful consideration of the timing of the published description of the Hering-Breuer reflex reveals the frequently mistaken attribution of this reflex to Hering Junior, rather than Hering Senior. Multiple factors likely contirbuted to this, including the similarity between their names and truncated versions of their names, as well as the large degree of overlap in their scientific interests. This paper serves to clarify the true origin of the eponym the Hering-Breuer reflex, i.e., Karl Ewald Konstantin Hering, for historical accuracy.

Acknowledgments The authors are grateful to Dr. Mehrnoush Gorjian from the Division of Neurological Surgery, Barrow Neurological Institute, St. Joseph's Hospital and Medical Center, Phoenix, Arizona, USA for assisting them in translating Hering Junior's 1924 German-language paper. They are also grateful to Ms. Margaret Wood Balch from Reynolds-Finley Historical Library for her assistance in obtaining some of the images used in this article.

\section{References}

1. Anonymous (1965) Heinrich Hering, Jr. (1866 - 1948): pathologic physiologist. JAMA 193:185-186
2. Bartolucci S, Forbis P (eds) (2005) Stedman's medical eponyms, 2nd edn. Lippincott Williams \& Wilkins, Baltimore

3. Baumann C (2005) Henry Head in Ewald Hering's laboratory in Prague 1884-1886: an early study on the nervous control of breathing. J Hist Neurosci 14:322-333

4. Breuer J (1868) Die Selbststeuerung der Athmung durch den Nervus vagus. Sitzungsberichte der kaiserlichen Akademie der Wissenschaften. Mathematisch-naturwissenschaftliche Classe (Wien) 58:909-937

5. Bridgeman B, Stark L (eds) (1977) Ewald Hering's theory of binocular vision (Die Lehre vom Binokularen Sehen). Plenum Press, New York

6. Burch GE, De Pasquale NP (1990) A history of electrocardiography. Normal Publishing, San Francisco

7. Corsini RJ (2002) The dictionary of psychology. BrunnerRoutledge, New York

8. Czermak JN (1866) Über mechanische Vagus Reizung beim Menschen. Jena Z Med Naturwiss 2:384-386

9. Dorland WAN (ed) (2011) Dorland's illustrated medical dictionary, 32nd edn. Elsevier Saunders, Philadelphia

10. Fleming PR (1997) A short history of cardiology. Editions Rodopi B.V, Atlanta

11. Gardner-Thorpe C (2001) Henry Head (1861 - 1940). In: Clifford RF (ed) Twentieth century neurology: the British contribution. Imperial College Press, London, pp 9-30

12. Glickstein M (2014) Neuroscience: an introduction. MIT Press, Boston

13. Hering HE (1903) Analysis of pulsus irregularis perpetuus. Prag Med Wocenschr 28:377-381

14. Hering HE (1924) Die Sinusreflexe vom Sinus caroticus werden durch einen Nerven (Sinusnerv) vermittelt, der ein Ast des Nervus glossopharyngeus ist. (Gleichzeitig 111. Mitteilung über den Carotisdruckversuch). Münch med Wschr 71:1265-1266

15. Hering KEK (1868) Die Selbststeuerung der Athmung durch den Nervus vagus. Sitzungsberichte der kaiserlichen Akademie der Wissenschaften. Mathematisch-naturwissenschaftliche Classe (Wien) 57:672-677

16. Janko J (1995) Mach and Hering's physiology of senses. In: Debru $\mathrm{C}$ (ed) Essays in the history of the physiological sciences: proceedings of a symposium held at the University Louis Pasteur, on March 26 - 27th, 1993. Rodopi B.V, Amsterdam, pp 88-98

17. Kellogg RH (1981) Historical perspectives. In: Hornbein T (ed) Regulation of breathing: part 1. Marcel Dekker, New York, pp 3-66

18. Lee JA (1968) Historical note: one hundred years ago (1). Anaesthesia 23:683

19. Navarra T (2003) Library of health and living: encyclopedia of asthma and respiratory disorders. Facts on File, Inc., New York

20. Rowell LB (2003) The cardiovascular system. In: Tipton CM (ed) Exercise physiology: people and ideas. Oxford University Press, New York, pp 98-137

21. Talbott JH (1970) A biographical history of medicine: excerpts and essays on the men and their work. Grune and Stratton, New York

22. Tipton CM (ed) (2014) History of exercise physiology. Human Kinetics, Champaign

23. White FA (2009) Physical signs in medicine and surgery: an atlas of rare, lost and forgotten physical signs. Philadelphia, Academic Press Group LLC., United States of America

24. Widdicombe J (2004) Henry Head and his paradoxical reflex. J Physiol 559:1-2

25. Zimmer HG (2004) Heinrich Ewald Hering and the carotid sinus reflex. Clin Cardiol 27:485-486 